\title{
Impact of Siberian forest fires on the atmosphere over the Korean Peninsula during summer 2014
}

\author{
Jinsang Jung ${ }^{1}$, Youngsook Lyu ${ }^{2}$, Minhee Lee ${ }^{2}$, Taekyung Hwang ${ }^{2}$, Sangil Lee ${ }^{1}$, and Sanghyub Oh${ }^{1}$ \\ ${ }^{1}$ Center for Gas Analysis, Korea Research Institute of Standards and Science (KRISS), Daejeon 34113, Republic of Korea \\ ${ }^{2}$ Department of Climate and Air Quality Research, National Institute of Environmental Research, \\ Daejeon 34944, Republic of Korea
}

Correspondence to: Jinsang Jung (jsjung@ kriss.re.kr)

Received: 16 December 2015 - Published in Atmos. Chem. Phys. Discuss.: 19 January 2016

Revised: 6 May 2016 - Accepted: 23 May 2016 - Published: 3 June 2016

\begin{abstract}
Extensive forest fires occurred during late July 2014 across the forested region of Siberia, Russia. Smoke plumes emitted from Siberian forest fires underwent long-range transport over Mongolia and northeast China to the Korean Peninsula, which is located $\sim 3000 \mathrm{~km}$ south of the Siberian forest. A notably high aerosol optical depth of $\sim 4$ was observed at a wavelength of $500 \mathrm{~nm}$ near the source of the Siberian forest fires. Smoke plumes reached $3-5 \mathrm{~km}$ in height near the source and fell below $2 \mathrm{~km}$ over the Korean Peninsula. Elevated concentrations of levoglucosan were observed $\left(119.7 \pm 6.0 \mathrm{ng} \mathrm{m}^{-3}\right)$, which were $\sim 4.5$ times higher than those observed during non-event periods in July 2014. During the middle of July 2014, a haze episode occurred that was primarily caused by the long-range transport of emission plumes originating from urban and industrial complexes in East China. Sharp increases in $\mathrm{SO}_{4}^{2-}$ concentrations $\left(23.1 \pm 2.1 \mathrm{\mu g} \mathrm{m}^{-3}\right)$ were observed during this episode. The haze caused by the long-range transport of Siberian forest fire emissions was clearly identified by relatively high organic carbon (OC) / elemental carbon (EC) ratios $(7.18 \pm 0.2)$ and $\mathrm{OC} / \mathrm{SO}_{4}^{2-}$ ratios $(1.31 \pm 0.07)$ compared with those of the Chinese haze episode (OC / EC ratio: $2.4 \pm 0.4 ; \mathrm{OC} / \mathrm{SO}_{4}^{2-}$ ratio: $0.21 \pm 0.05)$. Remote measurement techniques and chemical analyses of the haze plumes clearly show that the haze episode that occurred during late July 2014 was caused mainly by the long-range transport of smoke plumes emitted from Siberian forest fires.
\end{abstract}

\section{Introduction}

Forest fires emit large amounts of gaseous and particulate pollutants into the atmosphere, including carbon dioxide $\left(\mathrm{CO}_{2}\right)$, carbon monoxide $(\mathrm{CO})$, methane $\left(\mathrm{CH}_{4}\right)$, nitrogen oxides $\left(\mathrm{NO}_{x}\right)$, ammonia $\left(\mathrm{NH}_{3}\right)$, particulate matter $(\mathrm{PM})$, nonmethane hydrocarbon (NMHC), and other chemical species (Crutzen and Andreae, 1990). These pollutants alter the regional climate of downwind areas by altering ambient temperature, cloud properties, and precipitation efficiency (Jeong et al., 2008; Youn et al., 2011; Jeong et al., 2014). They also influence the air quality of downwind areas in urban, ocean, and Arctic regions through long-range atmospheric transport (Carvalho et al., 2011; Quennehe et al., 2012; Schreier et al., 2015).

During a severe forest fire episode in Moscow, Russia in August 2010, notably high concentrations of total carbon (mean of $202 \mu \mathrm{g} \mathrm{m}^{-3}$ ) and levoglucosan $\left(3.1 \mu \mathrm{g} \mathrm{m}^{-3}\right.$ ) were observed with an elevated organic carbon/elemental carbon (OC / EC) ratio of 27.4 (Popovicheva et al., 2014). Total carbon concentrations exceeded 10 times that during non-event periods in Moscow (Popovicheva et al., 2014). During severe forest fires in Siberia in May 2003, the surface $\mathrm{PM}_{10}$ (particulate matter with a diameter of $\leq 10 \mu \mathrm{m}$ ) and $\mathrm{O}_{3}$ concentrations in downwind areas increased by $5-30 \mu \mathrm{g} \mathrm{m}^{-3}$ and 3-20 ppbv, respectively, and this had important implications for air quality over East Asia (Jeong et al., 2008).

Russia is covered by over 800 million hectares of forest, which is equal to 50 billion tons of growing carbon stock, where annually about $1 \%$ is damaged by fires (Bondur, 2010; Popovicheva et al., 2014). Russian boreal forests are sub- 
jected to frequent wildfires. Each year, 10 000-35000 forest fires covering $5000-53000 \mathrm{~km}^{2}$ (including $4000-10000 \mathrm{~km}^{2}$ of high intensity, stand-replacing fires) are detected in actively protected portions of Russian forests (Bartalev et al., 1977; Isaev et al., 2002; Mei et al., 2011). Approximately 12 000-34 000 wildfires occurred every year between 1974 and 1993 (Conard and Eduard, 1996), which makes Siberia a major boreal forest fire area in global terms.

Frequent forest fires over Siberia have an impact on downwind areas in Mongolia, China, Korea, and the Northwest Pacific through long-range atmospheric transport (Kajii et al., 2002; Kanaya et al., 2003; Lee et al., 2005; Jeong et al., 2008; Youn et al., 2011). In May 2003, intense forest fires occurred over Siberia (Lee et al., 2005; Jeong et al., 2008; Youn et al., 2011). Satellite observations clearly show the transport of smoke plumes emitted from Siberian forest fires through Mongolia and eastern China, south to the Korean Peninsula (Lee et al., 2005). Simulations by Youn et al. (2011) showed a significant surface cooling of $-3.5 \mathrm{~K}$ over forested regions of Siberia. These simulations also showed that smoke aerosol affected large-scale circulation and resulted in an increase in average rainfall rates of $2.9 \mathrm{~mm} \mathrm{day}^{-1}$ over the Northwest Pacific. Jeong et al. (2008) reported that smoke plumes from Siberian forest fires in May 2003 acted mainly as a cooling agent, resulting in a negative radiative forcing of $-5.8 \mathrm{~W} \mathrm{~m}^{-2}$ at the surface over East Asia.

Severe wildfires occurred in the forested regions of Russia during summer 2014. The intensity of wildfires during this period was three times larger than in 2013. According to Russia's ITAR-TASS news agency, $\sim 12600$ forest fires had burned over 1.8 million hectares as of 16 July 2014. During this time, the most forest fires occurred in the Irkutsk and Yakutsk areas of Siberia. Over 200 forest fires covering 92000 hectares occurred in Siberian forested regions as of 16 July 2014 (http://tass.ru/en/russia/740878). MODIS satellite RGB images clearly show that these smoke plumes lasted more than a week and were transported south to Mongolia, northern China, and the Korean Peninsula.

In this study, we investigate the smoke plumes emitted from Siberian forest fires during late July 2014 and their long-range atmospheric transport to the Korean Peninsula. The transport mechanism of these plumes is investigated based on satellite image analysis and satellite-based lidar observations. We also characterize the chemical composition of these plumes over the Korean Peninsula. Chemical characteristics of anthropogenic pollutants from East China transported to the Korean Peninsula in the middle of July 2014 are also investigated and compared with those originating from Siberian forest fires.

\section{Experimental methods}

\subsection{Atmospheric aerosol sampling and sample preparation}

Table 1 summarizes the measurement parameters and conditions of this study. Daily $\mathrm{PM}_{2.5}$ (particulate matter with a diameter of $\leq 2.5 \mu \mathrm{m}$ ) sampling was carried out at a regional air-quality monitoring station $\left(36.19^{\circ} \mathrm{N}, 127.24^{\circ} \mathrm{E}\right)$ centrally located in Daejeon, Korea, from 4 to 31 July 2014. The samples were collected on pre-baked quartz fiber filters $(47 \mathrm{~mm}$ diameter, Pall-Life Sciences, USA) using an aerosol sampler (PMS-103, APM, Korea) at a flow rate of $16.7 \mathrm{~L} \mathrm{~min}^{-1}$ on the rooftop of a comprehensive monitoring building $(\sim 15 \mathrm{~m}$ above the ground) of the National Institute of Environmental Research in Korea. Before and after sampling, the filter samples were wrapped with aluminum foil and stored in a freezer at $-20^{\circ} \mathrm{C}$. A total of 31 filter samples were collected in this study, and additional field blank filters were collected before and after the sampling period.

Ultrapure water used in this study was prepared using a Labpure S1 filter and an ultra-violet (UV) lamp (ELGA, PureLab Ultra, USA). Resistivity and total organic carbon (TOC) values of the ultrapure water were maintained at $18.2 \mathrm{M} \Omega \mathrm{cm}^{-1}$ and $4 \mathrm{ppb}$, respectively. To measure carbohydrates and water-soluble ions, a quarter of each filter sample was extracted with $10 \mathrm{~mL}$ of ultrapure water under ultrasonication for $30 \mathrm{~min}$, and then passed through a disk filter (0.45 mm, Millipore, Millex-GV, Germany). Water extracts were stored in a refrigerator at $4{ }^{\circ} \mathrm{C}$ before analysis.

\subsection{Analysis of the chemical composition of fine particles}

Mass concentrations of $\mathrm{PM}_{2.5}$ were measured using a betaattenuation technique (BAM 1020, Met One Instruments), with an hourly averaging time resolution. The manufacturer reported the detection limit and measurement error of the beta-attenuation technique as $3.6 \mu \mathrm{g} \mathrm{m}^{-3}$ and $8 \%$, respectively. In addition to $\mathrm{PM}_{2.5}$ mass concentrations, the dailyaveraged chemical composition of $\mathrm{PM}_{2.5}$ was characterized through filter sampling and laboratory analysis. Because the $\mathrm{PM}_{2.5}$ chemical composition measurements were made on a daily basis, daily-averaged $\mathrm{PM}_{2.5}$ mass and chemical compositions were used in this study.

\subsubsection{Levoglucosan and mannosan analysis}

Levoglucosan and mannosan were analyzed using an improved high-performance anion-exchange chromatography (HPAEC) method with pulsed amperometric detection (PAD) (Engling et al., 2006; Jung et al., 2014). The HPAEC-PAD system uses an ion chromatograph consisting of an electrochemical detector and gold electrode unit, along with an AS40 auto-sampler (Dionex ICS-15000, Thermo Fisher Scientific, USA). Levoglucosan and mannosan were separated 


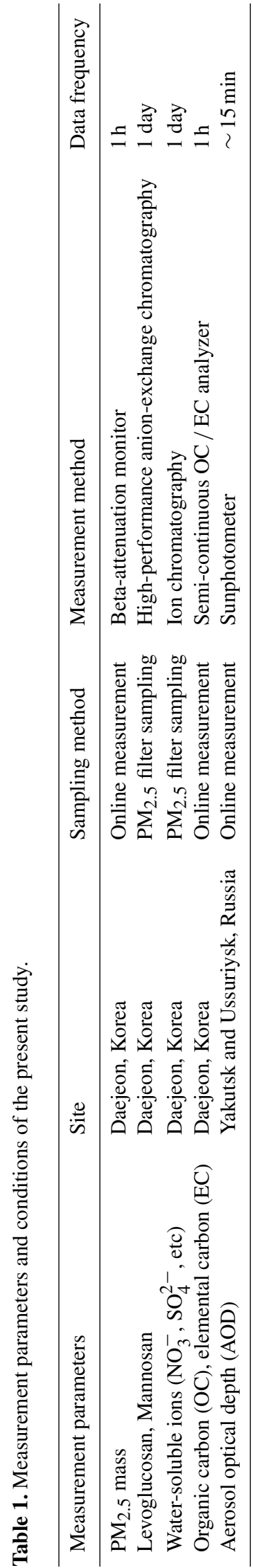

in a CarboPak MA1 analytical column $(4 \times 250 \mathrm{~mm})$ using a sodium hydroxide solution as the eluent. The detection limits of levoglucosan and mannosan were 3.0 and $0.7 \mathrm{ng} \mathrm{m}^{-3}$, respectively. The calculated values for analytical error, defined as the ratio of the standard deviation to the average value, obtained from triplicate analyses of filter samples, were 1.9 and $0.73 \%$ for levoglucosan and mannosan, respectively.

\subsubsection{Water-soluble inorganic ion analysis}

Water-soluble inorganic ions were analyzed using an ion chromatograph (Dionex ICS-15000, Thermo Fisher Scientific, USA). Nitrate $\left(\mathrm{NO}_{3}^{-}\right)$and sulfate $\left(\mathrm{SO}_{4}^{2-}\right)$ were separated using an IonPAC AS15 column with a $20 \mathrm{mM}$ potassium hydroxide $(\mathrm{KOH})$ eluent at a flow rate of $0.5 \mathrm{~mL} \mathrm{~min}^{-1}$. The detection limits of $\mathrm{NO}_{3}^{-}$and $\mathrm{SO}_{4}^{2-}$, which are defined as three times the standard deviation of field blanks, were 0.01 and $0.11 \mathrm{\mu} \mathrm{m}^{-3}$, respectively. The analytical errors associated with $\mathrm{NO}_{3}^{-}$and $\mathrm{SO}_{4}^{2-}$ were 2.3 and $1.7 \%$, respectively. Sodium $\left(\mathrm{Na}^{+}\right)$, ammonium $\left(\mathrm{NH}_{4}^{+}\right)$, potassium $\left(\mathrm{K}^{+}\right)$, calcium $\left(\mathrm{Ca}^{2+}\right)$, and magnesium $\left(\mathrm{Mg}^{2+}\right)$ were separated using an IonPac CS-12A column $(4 \times 250 \mathrm{~mm})$ with a $38 \mathrm{mM}$ methanesulfonic acid (MSA) eluent at a flow rate of $1.0 \mathrm{~mL} \mathrm{~min}^{-1}$. The detection limits of $\mathrm{NH}_{4}^{+}$and $\mathrm{K}^{+}$were 0.03 and $0.006 \mu \mathrm{g} \mathrm{m}^{-3}$, respectively. The analytical errors associated with $\mathrm{NH}_{4}^{+}$and $\mathrm{K}^{+}$were 1.4 and $0.73 \%$, respectively.

\subsubsection{Organic carbon/elemental carbon analysis}

Carbonaceous $\mathrm{PM}_{2.5}$ was measured using a semi-continuous organic carbon/elemental carbon (OC / EC) analyzer (Model RT3140, Sunset Lab). The air samples were drawn through a $\mathrm{PM}_{2.5}$ sharp-cut cyclone at $8 \mathrm{~L} \mathrm{~min}^{-1}$. The sampled aerosol was then passed through a multichannel parallel-plate denuder with a carbon-impregnated filter to remove semivolatile organic vapors, and then collected on a quartzfiber filter. The sampled aerosol was analyzed based on the thermal-optical transmittance (TOT) protocol for pyrolysis correction and the NIOSH (National Institute for Occupational Safety and Health) method 5040 temperature profile (Birch and Cary, 1996; Jung et al., 2010). External calibration was performed using known amounts of sucrose. The detection limit of both OC and EC is $0.5 \mu \mathrm{g} \mathrm{C} \mathrm{m}{ }^{-3}$ for a $1 \mathrm{~h}$ time resolution, according to the manufacturer. The uncertainty of OC and EC measurements has been reported as $5 \%$ (Polidori et al., 2006).

\subsection{Satellite aerosol optical depth and air mass backward trajectories}

The NOAA/ARL HYSPLIT (HYbrid Single-Particle Lagrangian Trajectory) air mass backward trajectory analysis (Draxler and Rolph, 2015; Rolph, 2015) and Moderate Resolution Imaging Spectro-radiometer (MODIS) satellite im- 


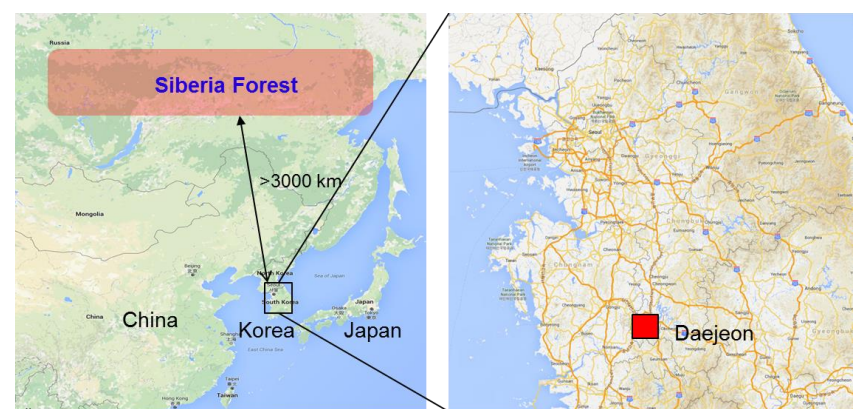

Figure 1. Map of the measurement site $\left(36.19^{\circ} \mathrm{N}, 127.24^{\circ} \mathrm{E}\right)$ in Daejeon, Korea (base map from Google Maps). The Siberian forest is located $\sim 3000 \mathrm{~km}$ north of the Korean Peninsula.

age analysis were used to characterize potential source regions and the transport pathway of the haze plume. Air mass backward trajectories ending at the sampling site $\left(36.19^{\circ} \mathrm{N}\right.$, $127.24^{\circ} \mathrm{E}$ ) in Daejeon, Korea were computed for heights of 200, 500, and $1000 \mathrm{~m}$ a.g.l. using the HYSPLIT model. All back trajectories were calculated at 00:00 and 12:00 UTC (09:00 and 21:00 LT, respectively), extending back $96 \mathrm{~h}$ with a $1 \mathrm{~h}$ time interval. The calculated air mass pathways indicate the general airflow pattern rather than the exact pathway of air masses, because the typical error in traveled distance is up to $20 \%$ for trajectories computed from analyzed wind fields (Stohl, 1998).

This study used aerosol optical depth (AOD) data retrieved using the NASA MODIS algorithm version V5.2, referred to as Collection 005 (C005) (Levy et al., 2007a, b), which are part of the MODIS Terra/Aqua Level-2 gridded atmospheric data product and are available on the MODIS web site (http://modis.gsfc.nasa.gov/). Cloud-screened level 1.5 sun-photometer data at sites in Yakutsk $\left(61.66^{\circ} \mathrm{N}\right.$, $129.37^{\circ} \mathrm{E} ; 118 \mathrm{~m}$ a.s.l.) and Ussuriysk $\left(43.70^{\circ} \mathrm{N}, 132.16^{\circ} \mathrm{E}\right.$; $280 \mathrm{~m}$ above sea level) in Russia were obtained from the AERONET site (http://aeronet.gsfc.nasa.gov). This study used total column-integrated spectral AOD determined using the AERONET algorithm (Dubovik and King, 2000).

CALIOP (Cloud-Aerosol Lidar with Orthogonal Polarization) is a space-based lidar system onboard the Cloud Aerosol Lidar and Infrared Pathfinder Satellite Observations (CALIPSO) satellite launched in 2006 (Winker et al., 2009). This study used version 2.30 data of total attenuated backscatter at $532 \mathrm{~nm}$. Expedited CALIPSO images were obtained from the CALIPSO website (http://www-calipso.larc.nasa.gov/products/lidar/ browse_images/show_calendar.php).

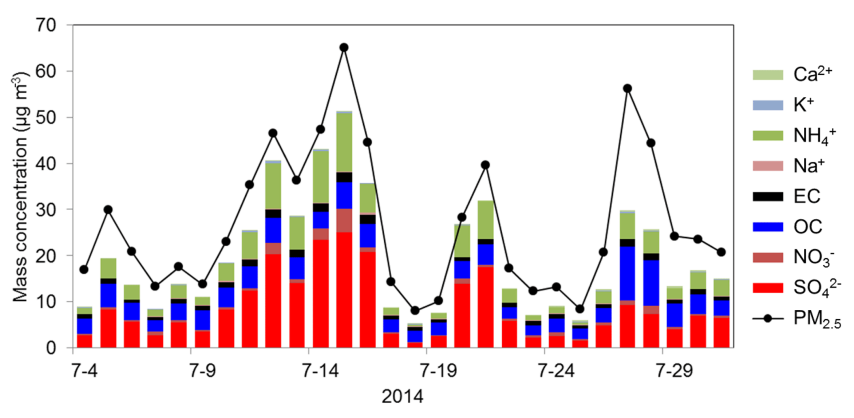

Figure 2. Temporal variations in the chemical components of fine particulate matter $\left(\mathrm{PM}_{2.5}\right)$ at the Daejeon site during July 2014.

\section{Results and discussion}

\subsection{Overview of the chemical composition of $\mathbf{P M}_{2.5}$}

Figure 2 shows temporal variations in the chemical composition of $\mathrm{PM}_{2.5}$ at the Daejeon site throughout the entire measurement period. Daily average $\mathrm{PM}_{2.5}$ mass concentrations ranged from 8.0 to $65.1 \mu \mathrm{g} \mathrm{m}^{-3}$ with an average of $26.8 \pm 15.4 \mathrm{\mu g} \mathrm{m}^{-3}$. Two peaks in $\mathrm{PM}_{2.5}$ mass concentration were observed during 12-16 July (first episode) and 27-28 July 2014 (second episode). PM $_{2.5}$ mass concentrations reached 65.1 and $56.2 \mu \mathrm{g} \mathrm{m}^{-3}$ during the first and second episodes, respectively. The temporal variations in the sum of $\mathrm{PM}_{2.5}$ chemical compositions show a similar pattern to that of total $\mathrm{PM}_{2.5}$ mass (Fig. 2). The largest contribution to $\mathrm{PM}_{2.5}$ mass during the measurement period came from $\mathrm{SO}_{4}^{2-}$, which had a mean of $8.8 \pm 7.0 \mu \mathrm{g} \mathrm{m}^{-3}$, followed by OC $\left(4.3 \pm 2.0 \mu \mathrm{g} \mathrm{m}^{-3}\right), \mathrm{NH}_{4}^{+}\left(4.3 \pm 3.3 \mu \mathrm{g} \mathrm{m}^{-3}\right)$, EC $\left(1.1 \pm 0.4 \mu \mathrm{g} \mathrm{m}^{-3}\right)$, and $\mathrm{NO}_{3}^{-}\left(1.0 \pm 1.1 \mu \mathrm{g} \mathrm{m}^{-3}\right)$, with minor contributions from $\mathrm{Ca}^{2+}, \mathrm{K}^{+}$, and $\mathrm{Na}^{+}$.

\subsection{Classification of haze episodes during summer 2014}

\subsubsection{Long-range transported smoke plumes from Siberian forest fires}

The MODIS RGB images clearly show severe smoke plumes over the Siberian forested region during late July 2014. Figure 3a shows a typical example from 25 July 2014 of satellite RGB images of the smoke plumes emitted from Siberian forest fires and their atmospheric transport to the south. Fire events over the Siberian forested region are indicated by red dots in Fig. 3a. It is clear that the smoke plumes originated in Siberia and were transported south to the Korean Peninsula across Mongolia and northeast China. HYSPLIT backward trajectory analyses (Fig. 3b) also indicate that the air masses originated in the Siberian forested region and were transported to the Korean Peninsula between 26 and 28 July 2014.

Figure 4 shows the horizontal distribution of AOD over East Asia from 23 to 28 July 2014. High values of AOD were observed over the Siberian forested region on 23 July, when 
(a)

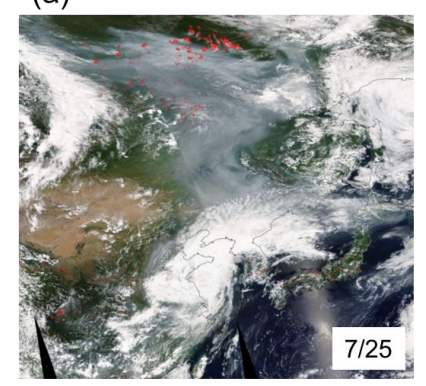

(b)

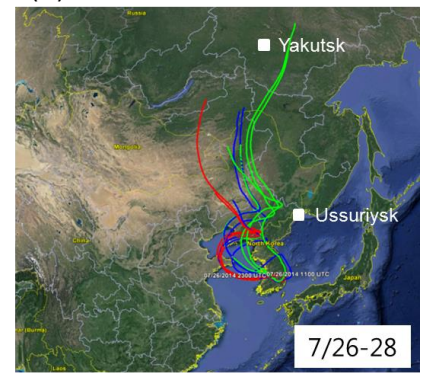

Figure 3. (a) MODIS RGB image on 25 July 2014 and (b) air mass backward trajectories between 26 and 28 July 2014 when smoke plumes originating from Siberian forest fires had an impact on the Korean Peninsula. Red, blue, and green in (b) represent air mass backward trajectories arriving at 200, 500, and $1000 \mathrm{~m}$ heights, respectively. The Yakutsk site $\left(61.66^{\circ} \mathrm{N}, 129.37^{\circ} \mathrm{E}\right)$ and Ussuriysk site $\left(43.70^{\circ} \mathrm{N}, 132.16^{\circ} \mathrm{E}\right)$ in (b) are AERONET sites in Russia.

forest fires occurred. Peak values of AOD were then observed to shift southward to northeast China and the Korean Peninsula from 23 to 28 July 2014 (Fig. 4). These horizontal distributions of AOD also support the transport of smoke plumes emitted from Siberian forest fires onto the Korean Peninsula during late July 2014.

Figure 5 shows temporal variations in AOD measured using a sun photometer at the Yakutsk and Ussuriysk sites. The Yakuksk site is located near the source of Siberian forest fire emissions, whereas the Ussuriysk site is located just to the north of the Korean Peninsula (Fig. 3). The measured AOD at the Yakutsk site started to increase from 23 July, and high AOD continued until 26 July 2014. The AOD dropped to $<0.5$ during 06:00-10:00 UTC, 25 July and increased again during 26 July. Because high AOD at the Yakutsk site was caused by transport of the Siberian smoke plume (Fig. 3), the sharp drop in AOD observed during 25 July can be explained by a change in wind direction at the Yakutsk site. The maximum AOD $(\sim 4)$ was observed at the Yakutsk site on 24 July 2014 during a Siberian forest fire event. High values for AOD were observed for 4 days at the Yakutsk site during the Siberian forest fire episode. Interestingly, a sharp increase in AOD was also observed at the Ussuriysk site on 24 July 2014. Spatial distributions of AOD from the MODIS satellite data (Fig. 4) clearly show that the Siberian smoke plumes extended over the Ussuriysk site during 24 July 2014. These results again suggest the transport of Siberian smoke plumes to the northern Korean Peninsula.

Figure 6 shows MODIS RGB images and vertical distributions of total attenuated backscatter at a wavelength of $532 \mathrm{~nm}$ measured by the CALIPSO satellite during 24, 25, and 27 July 2014. The left column in Fig. 6 shows MODIS RGB images taken during the Siberian smoke episode. These images show smoke plumes originating from the Siberian forest and being transported over northeastern China. The

yellow lines over the images in the left column of Fig. 6 indicate the route of the CALIPSO satellite, and correspond to the $x$ axis of the backscatter plots shown in the right column of Fig. 6. In the total attenuated backscatter measurement plots (Fig. 6, right), red and yellow represent atmospheric aerosol particles and white represents clouds. Figure $6 \mathrm{a}$ and b clearly show that between 24 and 25 July 2014 , a smoke layer existed approximately $3-5 \mathrm{~km}$ in height near the source region of the Siberian forest fires. As shown in Fig. 6c, the height of the smoke layer decreased to below $2 \mathrm{~km}$ on 27 July 2014 as it reached the Korean Peninsula.

The spatial distribution of AOD obtained from the MODIS and CALIPSO satellite observations, and the HYSPLIT air mass backward trajectory analysis indicate that smoke plumes originated from Siberian forest fires between 23 and 24 July 2014 and were transported over $3000 \mathrm{~km}$ south to the Korean Peninsula between 27 and 28 July 2014. Groundbased AOD measurements using a sun photometer near the Siberian forest fire area and on the Korean Peninsula also support the transport of a smoke plume originating from Siberian forest fires onto the Korean Peninsula. Thus, the smoke episode observed between 27 and 28 July 2014 is hereafter referred to as the Siberian forest fire episode.

\subsubsection{Long-range transported haze from Asian continental outflow}

Besides the haze episode caused by the long-range transport of smoke emitted from Siberian forest fires during late July 2014, another haze episode was observed at the Daejeon site between 14 and 16 July 2014, as shown in Fig. 2 . The MODIS RGB image from 14 July (Fig. 7) shows a severe haze plume originating from East China and extending to the Korean Peninsula across the Yellow Sea. HYSPLIT backward air mass trajectories also indicate the transport of air masses originating in East China to the Korean Peninsula over the Yellow Sea between 15 and 16 July 2014.

The region of East China extending from Beijing to Shanghai consists of heavily populated and industrialized cities (Chan and Yao, 2008). Large amounts of anthropogenic pollutants are emitted from this region (L. Li et al., 2015). Figure 8 shows the horizontal distribution of MODIS AOD over East Asia from 13 to 16 July 2014. A trail of high AOD extending from East China to the Korean Peninsula over the Yellow Sea is evident, which suggests that the haze episode observed between 14 and 16 July 2014 was caused primarily by long-range transport of pollutants originating from East China. Thus, the haze episode observed between 14 and 16 July is hereafter referred to as the Chinese haze episode. 

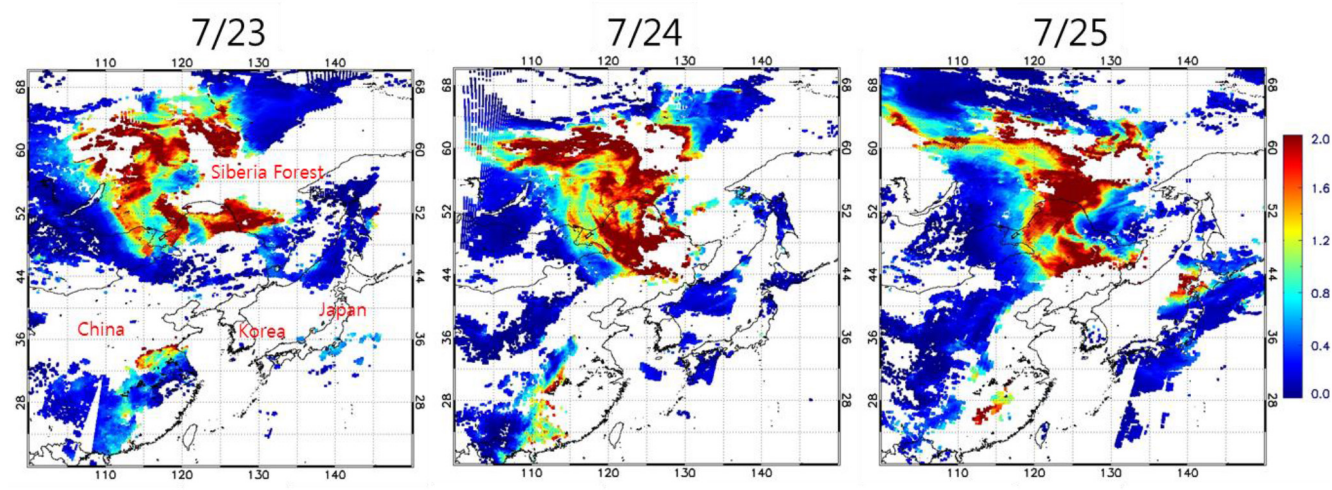

$7 / 26$

$7 / 27$

$7 / 28$
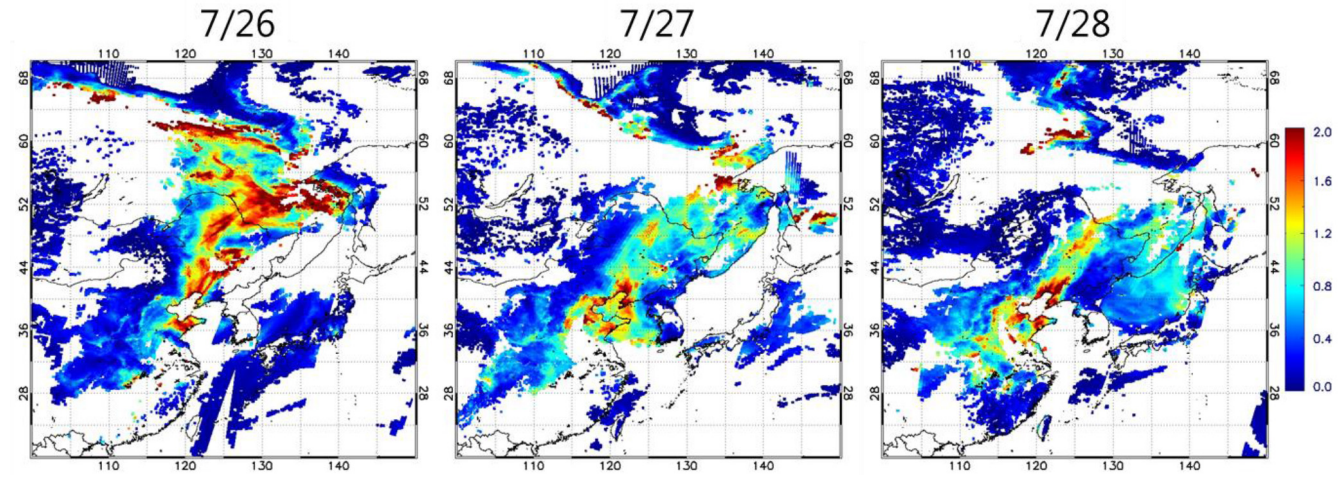

Figure 4. MODIS AOD over East Asia from 23 to 28 July 2014.

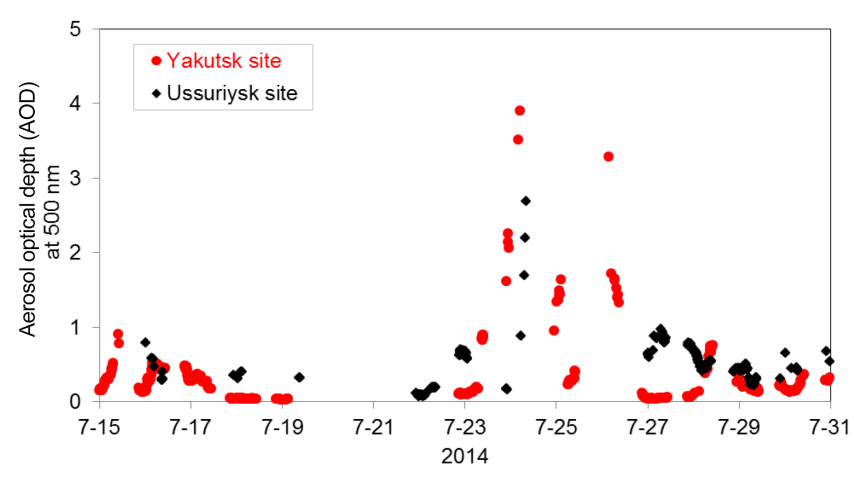

Figure 5. Temporal variations in AOD measured by a sun photometer at the Yakutsk and Ussuriysk sites in Russia during July 2014.

\subsection{Chemical characterization of long-range transported haze plumes}

\subsubsection{Comparison of $\mathbf{P M}_{2.5}$ chemical composition during haze episodes}

Figure 9 shows temporal variations in $\mathrm{PM}_{2.5}$ mass concentration and selected chemical components. During the Chinese haze episode, elevated concentrations of $\mathrm{SO}_{4}^{2-}$ $\left(23.1 \pm 2.1 \mu \mathrm{g} \mathrm{m}^{-3}\right)$ and $\mathrm{K}^{+}\left(0.27 \pm 0.08 \mu \mathrm{g} \mathrm{m}^{-3}\right)$ were observed, whereas elevated concentrations of levoglucosan $\left(119.6 \pm 6.0 \mathrm{ng} \mathrm{m}^{-3}\right), \mathrm{K}^{+}\left(0.33 \pm 0.07 \mu \mathrm{g} \mathrm{m}^{-3}\right)$, and $\mathrm{OC}$ $\left(10.8 \pm 1.1 \mu \mathrm{g} \mathrm{m}^{-3}\right)$ were measured during the Siberian forest fire episode. As shown in Fig. 9, OC concentrations were relatively constant throughout the measurement period, except during the Siberian forest fire episode. However, several peaks in $\mathrm{SO}_{4}^{2-}$ concentration were observed, with the highest peak occurring during the Chinese haze episode.

It has been reported that biomass burning (including biofuel) contributed $14.1 \%$ of the total VOC emissions in China during 2012, whereas in Anhui province the contribution of biomass combustion to VOC emissions was $28.7 \%$ (Wu et al., 2016). B. Li et al. (2015) reported that biomass burning contributed $58 \%$ of OC in Nanjing, China during summer 2012, suggesting that biomass burning is the dominant source of OC in this region. Du et al. (2011) classified the haze events in Shanghai, China during summer 2009 into three categories: biomass-burning induced (high $\mathrm{K}^{+}$, low $\mathrm{SO}_{4}^{2-}$ and $\mathrm{NO}_{3}^{-}$), complicated (high $\mathrm{SO}_{4}^{2-}$ and $\mathrm{NO}_{3}^{-}$, good correlation between $\mathrm{K}^{+}$and $\mathrm{SO}_{4}^{2-}$ and $\mathrm{NO}_{3}^{-}$), and secondary (high $\mathrm{SO}_{4}^{2-}$ and $\mathrm{NO}_{3}^{-}$, low $\mathrm{K}^{+}$) pollution. Because Anhui, Nanjing, and Shanghai are located near the source of the long-range transported Chinese haze (Fig. 8), the chemical composition of pollution in those areas can be used to understand the Chinese haze episode observed in this study. Temporal patterns in $\mathrm{K}^{+}$concentration are similar to those of $\mathrm{SO}_{4}^{2-}$, and a sharp increase in $\mathrm{SO}_{4}^{2-}$ concentration was observed during the Chinese haze episode (Fig. 9). This type of pollution episode is similar to the "complicated" pollution 
(a)

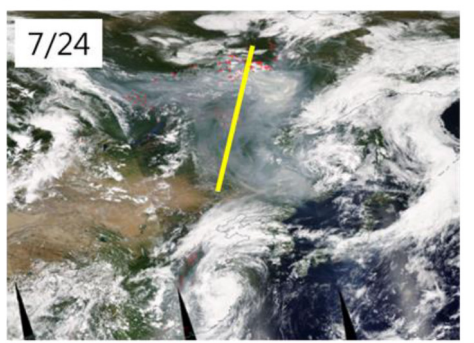

(b)

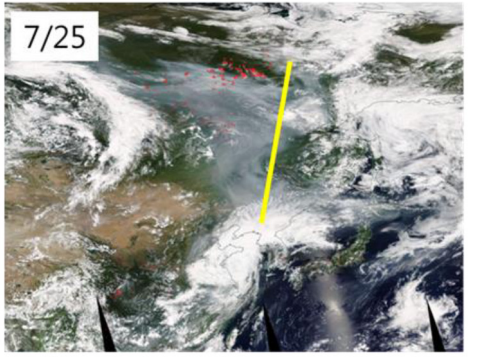

(c)

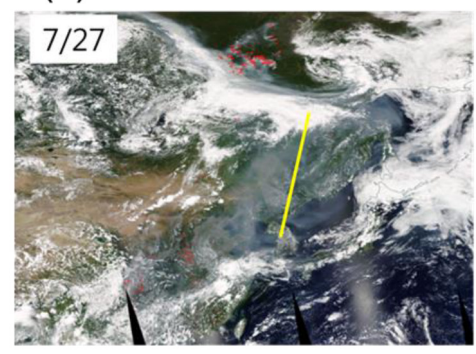

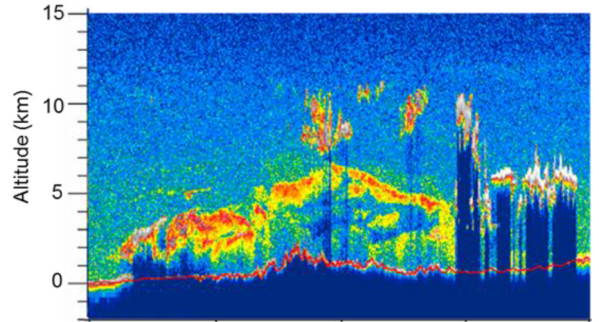
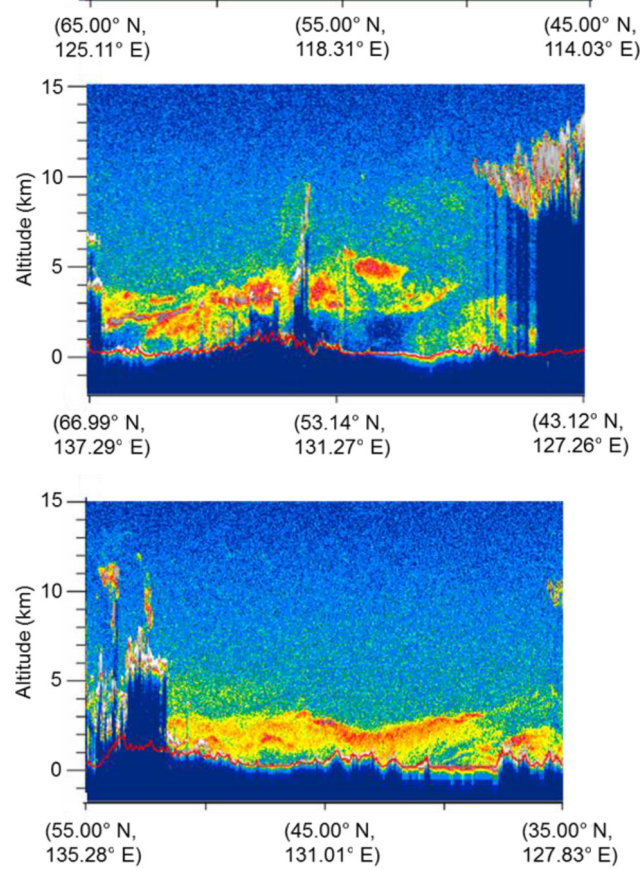

$532 \mathrm{~nm}$ Total

Attenuated

Backscatter, $\mathrm{km}^{-1} \mathrm{sr}^{-1}$

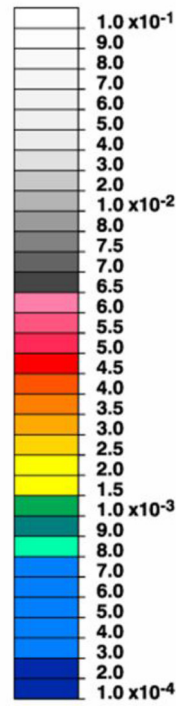

Figure 6. MODIS RGB images and vertical profiles of total attenuated backscatter at $532 \mathrm{~nm}$ measured by the CALIPSO satellite during (a) 24, (b) 25, and (c) 27 July 2014. Yellow lines in the MODIS RGB images indicate the route of the CALIPSO satellite, and correspond to the $x$ axis in the vertical profiles of total attenuated backscatter.

(a)

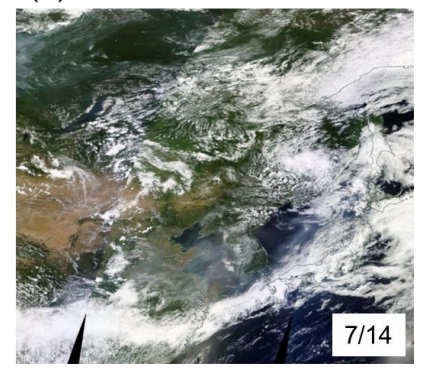

(b)

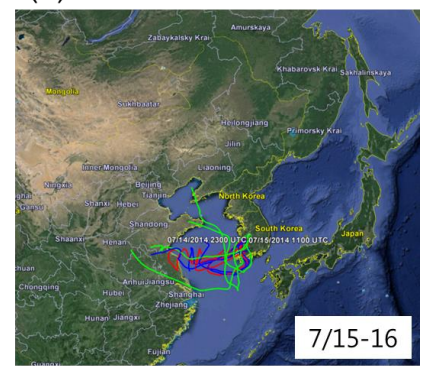

Figure 7. (a) MODIS RGB image on 14 July 2014 and (b) air mass backward trajectories between 15 and 16 July 2014 when haze plumes originating from East China had an impact on the Korean Peninsula. described by Du et al. (2011), and suggests that the Chinese haze episode was caused mainly by secondary aerosol such as $\mathrm{SO}_{4}^{2-}$ and $\mathrm{NH}_{4}^{+}$, rather than by biomass burning emissions.

Figure 10 shows relative contributions to $\mathrm{PM}_{2.5}$ mass during the Chinese haze and Siberian forest fire episodes. Concentrations of organic matter $(\mathrm{OM})$ were reconstructed from measured $\mathrm{OC}$ concentrations by multiplying the $\mathrm{OM} / \mathrm{OC}$ ratio of 1.8 that was measured using an aerosol mass spectrometer in Korea from spring to fall 2011 in the Asian continental outflow (Prof. T. Lee, personal communication, 2015). Huang et al. (2011) reported a similar OM / OC ratio of $1.77 \pm 0.08$ measured at a downwind site of the highly polluted Pearl River Delta cities in China during fall 2008. During the Chinese haze episode, $\mathrm{SO}_{4}^{2-}$ was found to be the dominant species in $\mathrm{PM}_{2.5}$ mass with an average contribution of $44.2 \%$, followed by $\mathrm{OM}(16.6 \%)$ and $\mathrm{NH}_{4}^{+}$ $(19.1 \%)$. This result suggests that the Chinese haze episode can be attributed primarily to anthropogenic pollutants (pos- 


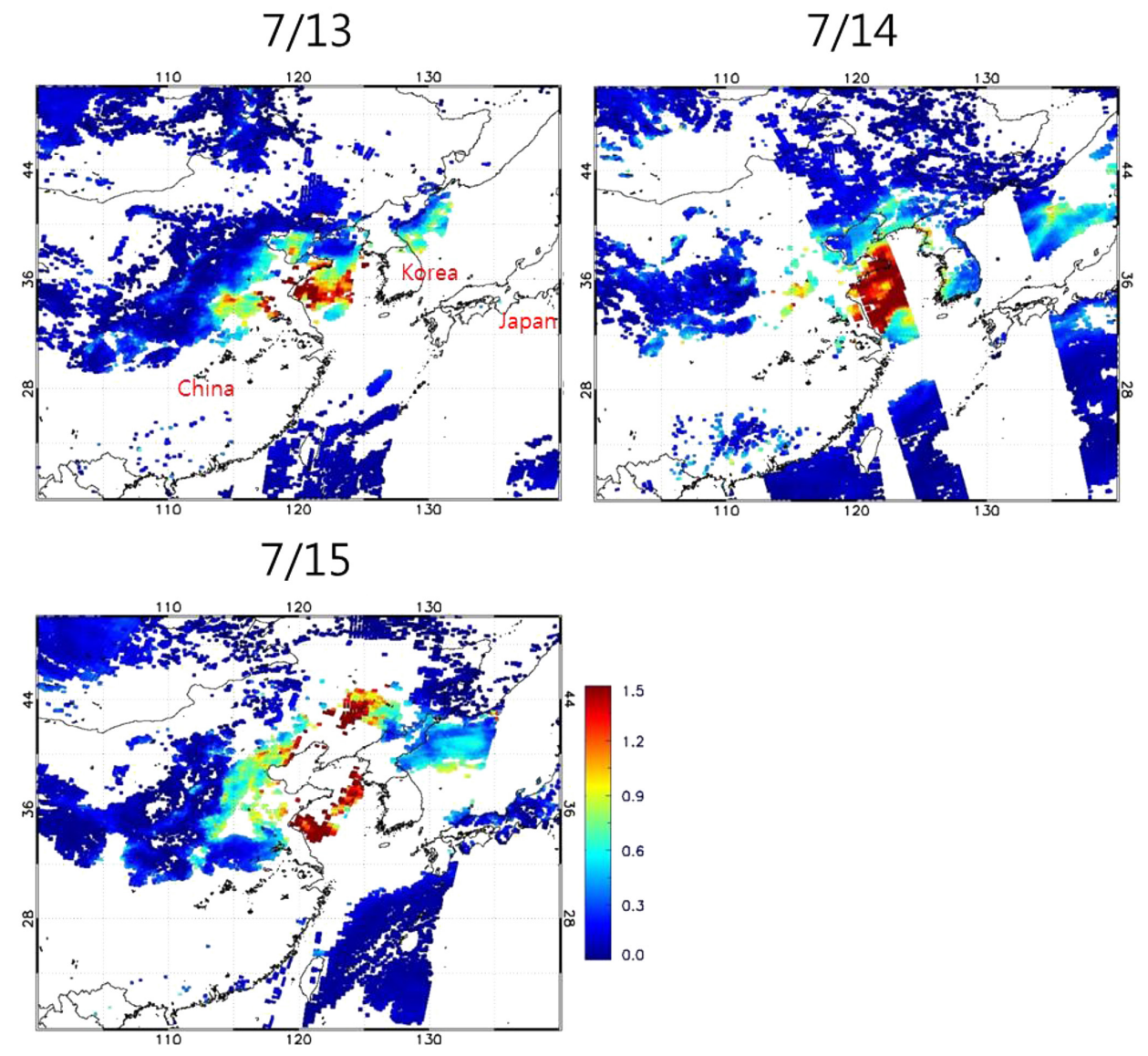

Figure 8. MODIS AOD over East Asia between 13 and 15 July 2014.

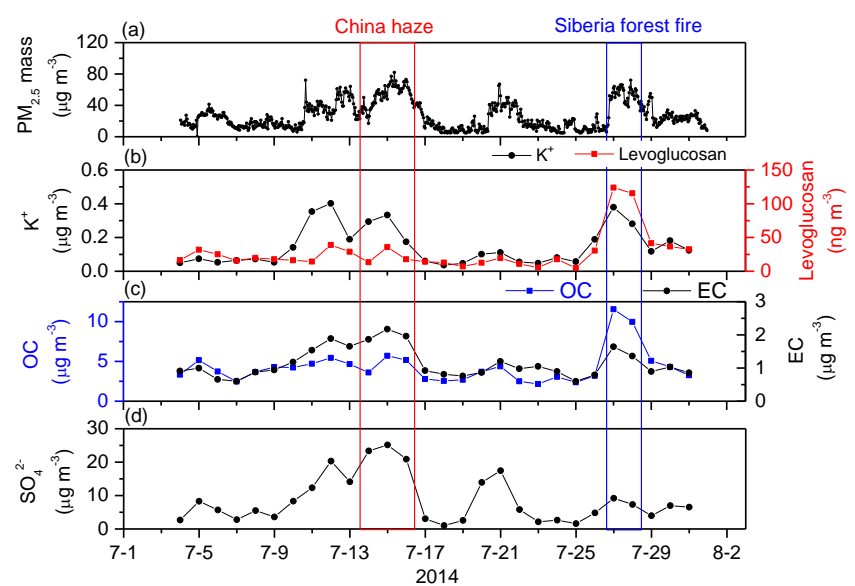

Figure 9. Temporal variations in $\mathrm{PM}_{2.5}$ mass, $\mathrm{K}^{+}$, levoglucosan, $\mathrm{OC}, \mathrm{EC}$, and $\mathrm{SO}_{4}^{2-}$ concentrations at the Daejeon site over the entire measurement period.

sibly emissions from industrial complexes and urban cities in East China). However, during the Siberian forest fire episode, $\mathrm{OM}$ was the dominant species in $\mathrm{PM}_{2.5}$ mass with an average contribution of $38.6 \%$, followed by $\mathrm{SO}_{4}^{2-}(16.5 \%)$ and $\mathrm{NH}_{4}^{+}(10.0 \%)$. The high concentration of OM indicates that the Siberian forest fire episode originated primarily from biomass burning.

\subsubsection{Comparison of biomass burning tracers during two haze episodes in the Daejeon atmosphere}

Levoglucosan and $\mathrm{K}^{+}$are widely used as indicators of biomass burning. Levoglucosan is formed during pyrolysis of cellulose and hemicellulose, and is not emitted from the burning of other materials, such as fossil fuels (Simoneit et al., 1999; Caseiro et al., 2009; Elias et al., 2001). However, caution is required when using $\mathrm{K}^{+}$as a biomass-burning tracer because $\mathrm{K}^{+}$can also be emitted from sea salt and soil (Pio et al., 2008). The mass concentration of biomass burning tracers and their ratios during the Siberian forest fire and Chinese haze episodes are summarized in Tables 2 and 3.

Significantly elevated concentrations of levoglucosan were observed during the Siberian forest fire episode, compared with smaller increases observed during the Chinese haze episode (Fig. 9). Concentrations of levoglucosan during the Siberian forest fire episode were measured to be $119.6 \pm 6.0 \mathrm{ng} \mathrm{m}^{-3}$, approximately 6 times higher than those 
Table 2. Summary of fine particle $\left(\mathrm{PM}_{2.5}\right)$ mass, and organic and inorganic chemical composition of $\mathrm{PM}_{2.5}$ particles during the Chinese haze and Siberian forest fire episodes measured at Daejeon, Korea during summer 2014.

\begin{tabular}{|c|c|c|c|c|}
\hline \multirow[t]{2}{*}{ Components } & \multirow[t]{2}{*}{ Unit } & Chinese haze $^{\mathrm{a}}$ & \multicolumn{2}{|c|}{ Siberian forest fire ${ }^{b}$} \\
\hline & & \multicolumn{3}{|c|}{ Range (Average $\pm 1 \sigma$ ) } \\
\hline $\mathrm{PM}_{2.5}$ mass & \multirow{7}{*}{$\left(\mu \mathrm{g} \mathrm{m}^{-3}\right)$} & $44.5-65.1(52.3 \pm 11.1)$ & $44.3-56.2$ & $(50.2 \pm 8.4)$ \\
\hline $\mathrm{SO}_{4}^{2-}$ & & $20.9-25.1 \quad(23.1 \pm 2.1)$ & 7.4-9.2 & $(8.3 \pm 1.3)$ \\
\hline $\mathrm{NO}_{3}^{-}$ & & $(2.8 \pm 2.1)$ & $1.1-1.7$ & $(1.4 \pm 0.4)$ \\
\hline $\mathrm{NH}_{4}^{+}$ & & $6.1-12.7 \quad(10.0 \pm 3.5)$ & $4.6-5.4$ & $(5.0 \pm 0.6)$ \\
\hline $\mathrm{OC}$ & & $(4.8 \pm 1.1)$ & $10.0-11.6$ & $(10.8 \pm 1.1)$ \\
\hline EC & & $(2.0 \pm 0.2)$ & $1.4-1.6$ & $(1.5 \pm 0.2)$ \\
\hline $\mathrm{K}^{+}$ & & $0.17-0.33(0.27 \pm 0.08)$ & $0.28-0.38$ & $(0.33 \pm 0.07)$ \\
\hline $\mathrm{OC} / \mathrm{EC}$ ratio & & $1.93-2.64 \quad(2.4 \pm 0.41)$ & $7.04-7.32$ & $(7.18 \pm 0.19)$ \\
\hline Levoglucosan & \multirow{2}{*}{$\left(\mathrm{ng} \mathrm{m}^{-3}\right)$} & $13.4-35.7(22.3 \pm 11.8)$ & \multicolumn{2}{|c|}{$115.4-123.9(119.6 \pm 6.0)$} \\
\hline Mannosan & & $(4.5 \pm 2.0)$ & $32.9-37.0$ & $(34.9 \pm 2.9)$ \\
\hline
\end{tabular}

a Chinese haze: $14-16$ July $2014{ }^{\text {b }}$ Siberian forest fire: $27-28$ July 2014

Table 3. Summary of ratios of biomass burning tracers during the Chinese haze and Siberian forest fire episodes, as measured at Daejeon, Korea in summer 2014

\begin{tabular}{lll}
\hline \multirow{2}{*}{ Components } & \multicolumn{1}{c}{ Chinese haze } & \multicolumn{1}{c}{ Siberian forest fire } \\
\cline { 2 - 3 } & & Range (Average $\pm 1 \sigma)$ \\
\hline Levoglucosan / Mannosan ratio & $4.41-5.22$ & $3.35-3.51$ \\
& $(4.81 \pm 0.41)$ & $(3.43 \pm 0.11)$ \\
\hline Levoglucosa $/ \mathrm{K}^{+}$ratio & $0.05-0.11$ & $0.33-0.41$ \\
& $(0.08 \pm 0.03)$ & $(0.37 \pm 0.06)$ \\
\hline
\end{tabular}

(a)

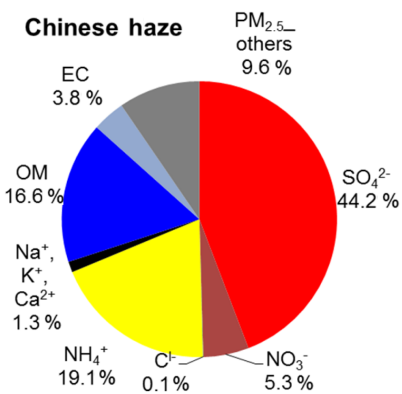

(b)

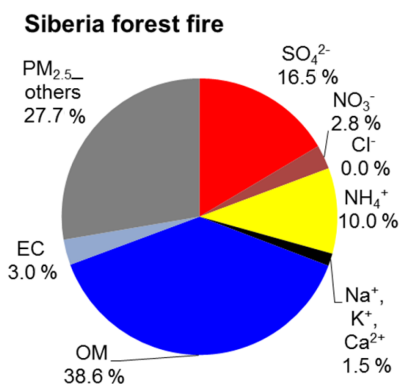

Figure 10. Average relative contributions to $\mathrm{PM}_{2.5}$ mass during the (a) Chinese haze and (b) Siberian forest fire episodes.

during the Chinese haze episode $\left(22.3 \pm 11.8 \mathrm{ng} \mathrm{m}^{-3}\right)$, as listed in Table 2. However, similar levels of $\mathrm{K}^{+}$were obtained during the Chinese haze $\left(0.27 \pm 0.08 \mu \mathrm{g} \mathrm{m}^{-3}\right)$ and Siberian forest fire $\left(0.33 \pm 0.07 \mu \mathrm{g} \mathrm{m}^{-3}\right)$ episodes. Thus, relatively high levoglucosan $/ \mathrm{K}^{+}$ratios were observed dur- ing the Siberian forest fire episode $(0.37 \pm 0.06)$ compared with those $(0.08 \pm 0.03)$ observed during the Chinese haze episode (Table 3). However, the levoglucosan / mannosan ratios observed during the Siberian forest fire episodes $(3.43 \pm 0.11)$ are similar to those observed during the Chinese haze episodes $(4.81 \pm 0.41)$, as shown in Table 3 .

OC concentrations increased as levoglucosan and $\mathrm{K}^{+}$concentrations increased during the Siberian forest fire episode (Fig. 11a). Elevated OC / EC ratios were also observed during the Siberian forest fire episode $(7.18 \pm 0.2)$. Simultaneous increases in $\mathrm{K}^{+}$, OC (Fig. 11b), and levoglucosan concentrations (Fig. 11c) during the Siberian forest fire episode suggest that the $\mathrm{K}^{+}$originated primarily from the smoke plume during the Siberian forest fire episode.

$\mathrm{OC}$ and levoglucosan concentrations observed during the Chinese haze episode are similar to those observed during the non-episode period, as shown in Fig. 11a. However, small increases in $\mathrm{K}^{+}$concentration were observed during the Chinese haze episode, as shown in Fig. $11 \mathrm{~b}$, resulting in relatively small levoglucosan $/ \mathrm{K}^{+}$ratios during the Chi- 
nese haze episode $(0.08 \pm 0.03)$ compared with those during the Siberian forest fire episode $(0.37 \pm 0.06)$. This difference in levoglucosan $/ \mathrm{K}^{+}$ratios can be explained as follows. First, different types of biomass burning might have occurred during the Chinese haze episode compared with the Siberian forest fire episode. It can be postulated that biomass-burning emissions with relatively low $\mathrm{OC} / \mathrm{K}^{+}$and levoglucosan $/ \mathrm{K}^{+}$ratios might have contributed to observations made on the Korean Peninsula during the Chinese haze episode.

Second, $\mathrm{K}^{+}$measured during the Chinese haze episode may have originated from sources other than biomass burning. Because $\mathrm{OC}$ is predominantly emitted from biomass burning, biomass-burning particles have relatively high OC/EC ratios and are generally well correlated with biomass burning tracers (Cao et al., 2008; Cheng et al., 2008; Popovicheva et al., 2014). The lack of significant increases in OC / EC ratio (2.4 \pm 0.4$)$, and OC and levoglucosan concentrations during the Chinese haze episode compared with nonepisode measurements suggests that the elevated $\mathrm{K}^{+}$concentrations observed during the Chinese haze episode might be due to emissions from other sources, such as soil, sea salt, or industrial complexes. Chow et al. (2004) reported that $3.9-12.5 \%$ of $\mathrm{PM}_{2.5}$ consisted of $\mathrm{K}^{+}$in stack samples from cement kiln manufacturing processes. Positive correlations of $\mathrm{K}^{+}$with $\mathrm{SO}_{4}^{2-}$ and $\mathrm{EC}$ concentrations during the Chinese haze episode (Fig. 9) also suggest that there were additional emissions of $\mathrm{K}^{+}$from anthropogenic sources other than biomass burning.

Elevated concentrations of levoglucosan and OC, and relatively high OC / EC ratios (7.18 \pm 0.2$)$ suggest that the haze episode that occurred during late July 2014 was caused primarily by the long-range transport of smoke emitted from Siberian forest fires. However, significantly elevated $\mathrm{SO}_{4}^{2-}$ concentrations with relatively weak increases in $\mathrm{OC}$ and levoglucosan concentrations and lower OC / EC ratios indicate that the Chinese haze episode was caused primarily by anthropogenic pollutants emitted from industrial complexes and urban cities in East China, with relatively little contribution from biomass burning.

\subsubsection{Tracking major sources of biomass burning during the Siberian forest fire episode}

Levoglucosan / mannosan (Levo / Man) ratios and levoglucosan $/ \mathrm{K}^{+}$(Levo $/ \mathrm{K}^{+}$) ratios observed during the Siberian forest fire episode are compared with those from previous chamber experiments and field studies in Fig. 12. Hardwood burning produces higher Levo / Man ratios with a mean value of 26 (range: 2.2-195) (Fine et al., 2001, 2002, 2004a, b; Schauer et al., 2001; Engling et al., 2006; Schmidl et al., 2008a; Bari et al., 2009; Gonçalves et al., 2010), whereas softwood burning has lower Levo / Man ratios (mean: 4.3, range: 2.5-6.7) (Fine et al., 2001, 2002, 2004a, b; Schauer et al., 2001; Hays et al., 2002; Engling et al., 2006; Iinuma (a)

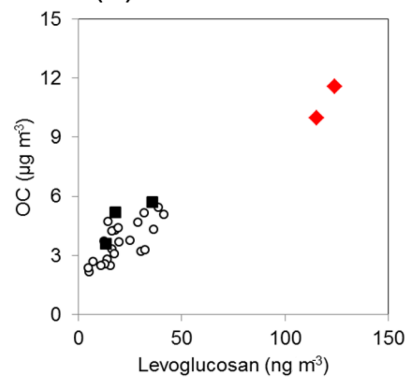

(c)

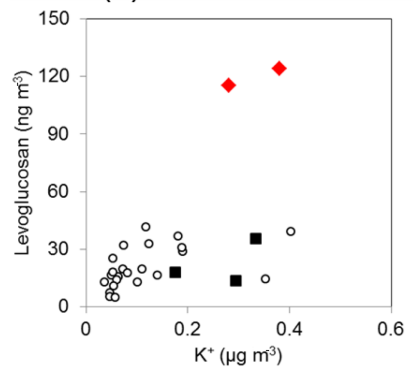

(b)

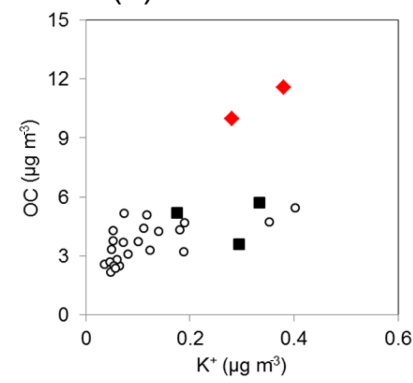

(d)

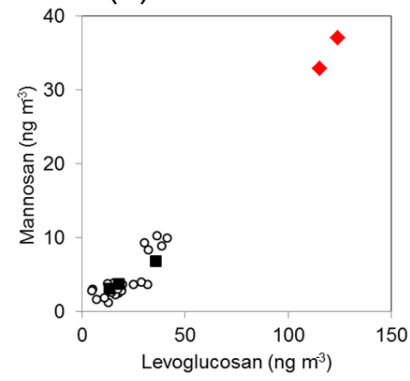

Figure 11. Scatter plots of OC vs. (a) levoglucosan and (b) $\mathrm{K}^{+}$, and levoglucosan versus (c) $\mathrm{K}^{+}$and (d) mannosan between 4 and 31 July 2014. Filled black and red diamonds represent the Chinese haze and Siberian forest fire episodes, respectively. Open black circles represent the remaining sampling days in July 2014.

et al., 2007; Schmidl et al., 2008a; Gonçalves et al., 2010). Grass (mean: 18, range: 9.2-39) and crop residue burnings (mean: 29, range: $12-55$ ) have relatively high Levo / Man ratios compared with leaf burning (mean: 5.6, range: 5.1-6.0) (Sheesley et al., 2003; Engling et al., 2006, 2009; Sullivan et al., 2008; Schmidl et al., 2008b; Oanh et al., 2011; Cheng et al., 2013). Levo / Man ratios (mean: 5.3) observed during the smoke episode in Moscow, Russia in summer 2010 are similar to those reported for softwood and leaf burning (Popovicheva et al., 2014).

Because levoglucosan and mannosan are emitted from similar burning processes, the Levo / Man ratio can be used to track the type of biomass burning. Levo / Man ratios observed during the Siberian forest fire episode are similar to those obtained from the softwood and leaf burning experiments, and the smoke episode in Moscow, Russia during summer 2010. However, Levo / Man ratios during the Siberian forest fire episode are much lower than those reported for hardwood, grass, and crop residue burning.

Hardwood and softwood burning yields relatively high Levo / $\mathrm{K}^{+}$ratios, with mean values of 26 and 46, and ranges of 2.2-195 and 4.6-261, respectively (Fine et al., 2001, 2002, 2004a, b; Schauer et al., 2001; Hays et al., 2002; Engling et al., 2006; Iinuma et al., 2007; Schmidl et al., 2008a; Bari et al., 2009; Gonçalves et al., 2010). However, grass, crop residue, and leaf burning have relatively low Levo $/ \mathrm{K}^{+}$ratios, with mean values of $3.3,0.53$, and 2.9 , and ranges 
(a)

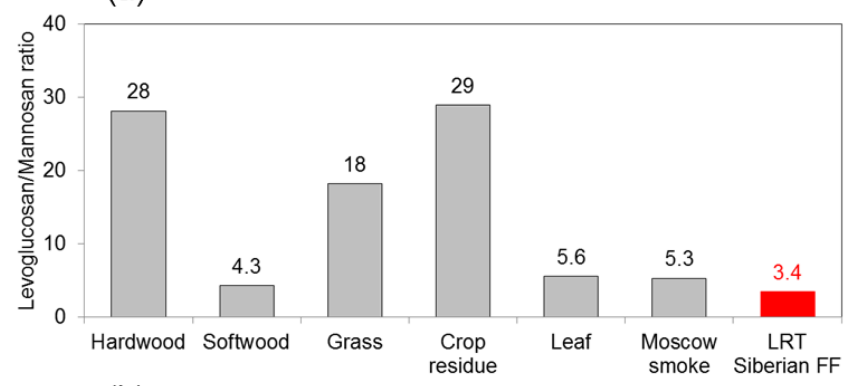

(b)

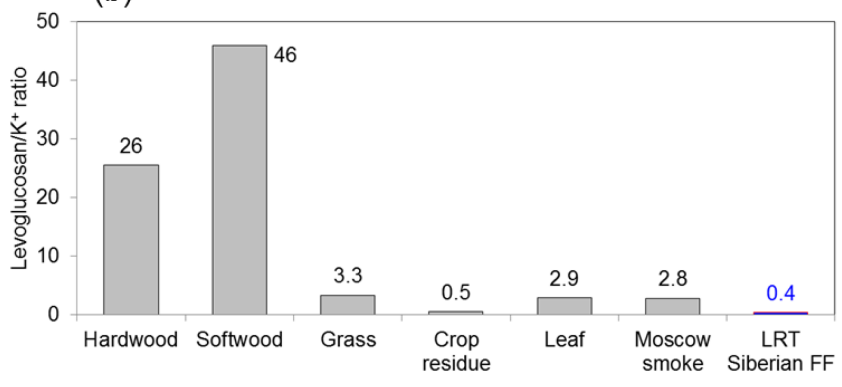

Figure 12. (a) Levoglucosan to mannosan ratios and (b) levoglucosan to $\mathrm{K}^{+}$ratios obtained from previous chamber studies, extreme smoke episodes in Moscow, Russia in summer 2010, and the Siberian forest fire episode. Hardwoods: Fine et al. (2001, 2002, 2004a, b), Schauer et al. (2001), Engling et al. (2006), Schmidl et al. (2008a), Gonçalves et al. (2010), Bari et al. (2009); Softwoods: Fine et al. (2001, 2002, 2004a, b), Schauer et al. (2001), Engling et al. (2006), Hay et al. (2002), Schmidl et al. (2008a), Goncalves et al. (2010), Iinuma et al. (2007), Cheng et al. (2013); Grass: Sullivan et al. (2008); Crop residue: Sullivan et al. (2008), Oanh et al. (2011), Sheesley et al. (2003), Engling et al. (2009), Cheng et al. (2013); Leaf: Schmidl et al. (2008b); Moscow smoke: Popovicheva et al. (2014); LRT Siberia FF: This study.

of $0.06-9.5,0.1-1.2$, and 2.4-3.4, respectively (Sheesley et al., 2003; Engling et al., 2006, 2009; Sullivan et al., 2008; Schmidl et al., 2008b; Oanh et al., 2011; Cheng et al., 2013). Levo $/ \mathrm{K}^{+}$ratios (mean: 2.8) observed during the smoke episode in Moscow, Russia in summer 2010 are similar to those reported for grass, crop residue, and leaf burning (Popovicheva et al., 2014).

Levo $/ \mathrm{K}^{+}$ratios observed during the Siberian forest fire episode are close to those reported for grass, crop residue, and leaf burning, as well as to the ratios of the smoke episode in Moscow, but much lower than those from hardwood and softwood burning (Fig. 12b). Levoglucosan can be removed through photo-oxidative decay during atmospheric transport (Hennigan et al., 2010), but $\mathrm{K}^{+}$is relatively stable in the atmosphere. Thus, Levo $/ \mathrm{K}^{+}$ratios can decrease during longrange atmospheric transport. The Levo $/ \mathrm{K}^{+}$ratios observed during the Siberian forest fire episode were lower than those during the smoke episode in Moscow, Russia in summer 2010, which can be explained by photochemical degradation of levoglucosan during long-range atmospheric transport.
Based on a comparison of biomass burning tracers from various sources (Fig. 12), it is suggested that smoke aerosol emitted during the Siberian forest fire episode originated mainly from the burning of forest leaves in Siberia prior to their long-range atmospheric transport. Smoke aerosol observed during the smoke episode in Moscow, Russia in summer 2010 have similar Levo / Man and Levo / $\mathrm{K}^{+}$ratios to those from leaf burning (Fig. 12). These observations suggest that smoke episodes in the Russian forest originate primarily from the burning of forest leaves.

\section{Conclusions}

This study investigated the long-range transport of smoke plumes emitted from Siberian forest fires during late July 2014. Smoke plumes emitted from Siberian forest fires are generally transported to the Northwest Pacific by prevailing westerlies. However, the haze plume that occurred during late July 2014 had a significant impact on the Korean Peninsula, which is located $\sim 3000 \mathrm{~km}$ south of the Siberian forest. From the spatial distributions of AOD obtained from the MODIS satellite, CALIPSO satellite observations, and HYSPILT air mass backward trajectory analyses, it is evident that smoke plumes originating from Siberian forest fires between 23 and 24 July 2014 were transported over $3000 \mathrm{~km}$ south to the Korean Peninsula between 27 and 28 July 2014. During this episode, elevated concentrations of levoglucosan $\left(119.6 \pm 6.0 \mathrm{ng} \mathrm{m}^{-3}\right)$ and $\mathrm{K}^{+}\left(0.33 \pm 0.07 \mu \mathrm{g} \mathrm{m}^{-3}\right)$, and high $\mathrm{OC} / \mathrm{EC}$ ratios $(7.18 \pm 0.2)$ were observed at a measurement site in Daejeon, Korea. These results suggest that the haze episode that occurred during late July 2014 was caused mainly by the long-range transport of smoke plumes emitted from Siberian forest fires. The Siberian smoke episode is clearly distinguished from a haze episode caused by the longrange transport of anthropogenic pollutants emitted from East China, which was characterized by elevated $\mathrm{SO}_{4}^{2-}$ concentrations and weak increases in $\mathrm{OC}$ and levoglucosan concentrations.

Acknowledgements. This work was conducted as part of a coresearch project between National Institute of Environmental Research (NIER) and the Korean Research Institute of Standards and Science (KRISS). This work was funded by the National Research Foundation under grant NRF-2015R1C1A1A02036580. We thank B. Holben and M. Panchenko for their efforts in establishing and maintaining the Yakutsk and Ussuriysk AERONET sites in Russia. The authors gratefully acknowledge the NOAA Air Resources Laboratory (ARL) for the provision of the HYSPLIT transport and dispersion model and the READY website (http://www.arl.noaa.gov/ready.html) used in this publication. The authors also thank NASA (USA) for making available the Collection 005 Level-2 MODIS data.

Edited by: A. Pszenny 


\section{References}

Bari, M. A., Baumbach, G., Kuch, B., and Scheffknecht, G.: Wood smoke as a source of particle-phase organic compounds in residential areas, Atmos. Environ., 43, 4722-4732, 2009.

Bartalev, S. A., Korovin, G. N., and Shlepak, B. V.: Assessments of Forest Fire Recognition, Using the NOAA AVHRR Radiometers, in: Proceedings of International Forum on Problems in Science, Technology and Education, II, Moscow, 22-25, 1977.

Birch, M. E. and Cary, R. A.: Elemental carbon-based method for monitoring occupational exposure to particulate diesel exhaust, Aerosol Sci. Tech., 25, 221-241, 1996.

Bondur, V. G.: Importance of aerospace remote sensing approach to the monitoring of nature fire in Russia, International Forest Fire News (IFFN), 40, 43-57, 2010.

Cao, G., Zhang, X., Gong, S., and Zheng, F.: Investigation on emission factors of particulate matter and gaseous pollutants from crop residue burning, J. Environ. Sci., 20, 50-55, 2008.

Carvalho, A., Monteiro, A., Flannigan, M., Solman, S., Miranda, A. I., and Borrego, C.: Forest fires in a changing climate and their impacts on air quality, Atmos. Environ., 45, 5545-5553, 2011.

Caseiro, A., Bauer, H., Schmidl, C., Pio, C. A., and Puxbaum, H.: Wood burning impact on $\mathrm{PM}_{10}$ in three Austrian regions, Atmos. Environ., 43, 2186-2195, 2009.

Chan, C. K. and Yao, X.: Air pollution in mega cities in China, Atmos. Environ., 42, 1-42, 2008.

Cheng, M. T., Horng, C. L., Su, Y. R., Lin, L. K., Lin, Y. C., and Chou, C. K.: Particulate matter characteristics during agricultural waste burning in Taichung City, Taiwan, J. Hazard. Mater., 165, 187-192, 2008.

Cheng, Y., Engling, G., He, K.-B., Duan, F.-K., Ma, Y.-L., Du, Z.Y., Liu, J.-M., Zheng, M., and Weber, R. J.: Biomass burning contribution to Beijing aerosol, Atmos. Chem. Phys., 13, 77657781, doi:10.5194/acp-13-7765-2013, 2013.

Chow, J. C., Watson, J. G., Kuhns, H., Etyemezian, V., Lowenthal, D. H., Crow, D., Kohl, S. D., Engelbrecht, J. P., and Green, M. C.: Source profiles for industrial, mobile, and area sources in the Big Bend Regional Aerosol Visibility and Observational study, Chemosphere, 54, 185-208, 2004.

Conard, S. G. and Ivanova, G. A.: A Differential Approach to Numerical Assessment of Forest Fire Carbon Emissions, Lesovedenie (Forestry), 3, 28-35, 1988.

Crutzen, P. J. and Andreae, M. O.: Biomass burning in the tropics: Impact on atmospheric chemistry and biogeochemical cycles, Science, 250, 1669-1678, 1990.

Draxler, R. R. and Rolph, G. D.: HYSPLIT (HYbrid Single-Particle Lagrangian Integrated Trajectory) Model access via NOAA ARL READY Website, http://www.arl.noaa.gov/HYSPLIT.php, NOAA Air Resources Laboratory, Silver Spring, MD, 2015.

Du, H., Kong, L., Cheng, T., Chen, J., Du, J., Li, L., Xia, X., Leng, C., and Huang, G.: Insights into summertime haze pollution events over Shanghai based on online water-soluble ionic composition of aerosols, Atmos. Environ., 45, 5131-5137, 2011.

Dubovik, O. and King, M. D.: A flexible inversion algorithm for retrieval of aerosol optical properties from Sun and sky radiance measurements, J. Geophys. Res., 105, 20673-20696, 2000.

Elias, V. O., Simoneit, B. R. T., Cordeiro, R. C., and Turcq, B.: Evaluating levoglucosan as an indicator of biomass burning in Carajás, Amazônia: a comparison to the charcoal record, Geochim. Cosmochim. Acta, 65, 267-272, 2001.
Engling, G., Carrico, C.M., Kreidenweis, S. M., Collett Jr., J. L., Day, D. E., Malm, W. C., Lincoln, L., Hao, W. M., Iinuma, Y., and Herrmann, H.: Determination of levoglucosan in biomass combustion aerosol by high-performance anion-exchange chromatography with pulsed amperometric detection, Atmos. Environ., 40, S299-S311, 2006.

Engling, G., Lee, J. J., Tsai, Y. W., Lung, S. C. C., Chou, C. C. K., and Chan, C. Y.: Size-resolved anhydrosugar composition in smoke aerosol from controlled field burning of rice straw, Aerosol Sci. Tech., 43, 662-672, 2009.

Fine, P. M., Cass, G. R., and Simoneit, B. R. T.: Chemical characterization of fine particle emissions from fireplace combustion of woods grown in the northeastern United States, Environ. Sci. Tech., 35, 2665-2675, 2001.

Fine, P. M., Cass, G. R., and Simoneit, B. R. T.: Chemical characterization of fine particle emissions from the fireplace combustion of woods grown in the southern United States, Environ. Sci. Tech., 36, 1442-1451, 2002.

Fine, P. M., Cass, G. R., and Simoneit, B. R. T.: Chemical characterization of fine particle emissions from the fireplace combustion of wood types grown in the midwestern and western United States, Environ. Eng. Sci., 21, 387-409, 2004a.

Fine, P. M., Cass G. R., and Simoneit, B. R. T.: Chemical characterization of fine particle emissions from the wood stove combustion of prevalent United States tree species, Environ. Eng. Sci. 21, 705-721, 2004b.

Gonçalves, C., Alves, C., Evtyugina, M., Mirante, F., Pio, C., Caseiro, A., Schmidl, C., Bauer, H., and Carvalho, F.: Characterisation of $\mathrm{PM}_{10}$ emissions from wood stove combustion of common woods grown in Portugal, Atmos. Environ., 44, 4474-4480, 2010.

Hays, M. D., Geron, C. D., Linna, K. J., Smith, N. D., and Schauer, J. J.: Speciation of gas-phase and fine particle emissions from burning of foliar fuels, Environ. Sci. Tech., 36, 2281-2295, 2002.

Hennigan, C. J., Sullivan, A. P., Collett Jr., J. L., and Robinson, A. L.: Levoglucosan stability in biomass burning particles exposed to hydroxyl radicals, Geophys. Res. Lett., 37, L09806, doi:10.1029/2010GL043088, 2010.

Huang, X.-F., He, L.-Y., Hu, M., Canagaratna, M. R., Kroll, J. H., Ng, N. L., Zhang, Y.-H., Lin, Y., Xue, L., Sun, T.-L., Liu, X.-G., Shao, M., Jayne, J. T., and Worsnop, D. R.: Characterization of submicron aerosols at a rural site in Pearl River Delta of China using an Aerodyne High-Resolution Aerosol Mass Spectrometer, Atmos. Chem. Phys., 11, 1865-1877, doi:10.5194/acp-11-18652011, 2011.

Iinuma, Y., Brüggemann, E., Gnauk, T., Müller, K., Andreae, M. O., Helas, G., Parmar, R., and Herrmann, H.: Source characterization of biomass burning particles: The combustion of selected European conifers, African hardwood, savanna grass, and German and Indonesian peat, J. Geophys. Res., 112, D08209, doi:10.1029/2006JD007120, 2007.

Isaev, A. S., Korovin, G. N., Bartalev, S. A., Ershov, D. V., Janetos, A., Kasischke, E. S., Shugart, H. H., French, N. H. F., Orlick, B. E., and Murphy, T. L.: Using Remote Sensing to Assess Russian Forest Fire Carbon Emissions, Climatic Change, 55, 235-249, 2002.

Jeong, H., Chung, C. E., van Noije, T., and Takemura, T.: Relationship between fine-mode AOD and precipitation on sea- 
sonal and interannual time scales, Tellus Ser. B, 66, 23037, doi:10.3402/tellusb.v66.23037, 2014.

Jeong, J. I., Park, R. J., and Youn, D.: Effects of Siberian forest fires on air quality in East Asia during May 2003 and its climate implication, Atmos. Environ., 42, 8910-8922, doi:10.1016/j.atmosenv.2008.08.037, 2008.

Jung, J., Kim, Y. J., Lee, K. Y., Cayetano, M. G., Batmunkh, T., Koo, J.-H., and Kim, J.: Spectral optical properties of longrange transport Asian dust and pollution aerosols over Northeast Asia in 2007 and 2008, Atmos. Chem. Phys., 10, 5391-5408, doi:10.5194/acp-10-5391-2010, 2010

Jung, J., Lee, S., Kim, H., Kim, D., Lee, H., and Oh, S.: Quantitative determination of the biomass-burning contribution to atmospheric carbonaceous aerosols in Daejeon, Korea, during the rice harvest period, Atmos. Environ. 89, 642-650, 2014.

Kajii, Y., Kato, S., Streets, D. G., Tsai, N. Y., Shvidenko, A., Nilsson, S., Minko, N. P., Abushenko, N., Altyntsev, D., and Khodzer, T. V.: Boreal forest fires in Siberia in 1998: estimation of area and emissions of pollutants by AVHRR satellite data, J. Geophys. Res., 107, 4745, doi:10.1029/2001JD001078, 2002.

Kanaya, Y., Kajii, Y., and Akimoto, H.: Solar actinic flux and photolysis frequency determinations by radiometers and a radiative transfer model at Rishiri Island: comparisons, cloud effects, and detection of an aerosol plume from Russian forest fires, Atmos. Environ., 37, 2463-2475, 2003.

Lee, K. H., Kim, J. E., Kim, Y. J., Kim, J., and Von HoyningenHuene, W.: Impact of the smoke aerosol from Russian forest fires on the atmospheric environment over Korea during May 2003, Atmos. Environ., 39, 85-99, 2005.

Levy, R. C., Remer, L. A., and Dubovik, O.: Global aerosol optical properties and application 15 to Moderate Resolution Imaging Spectroradiometer aerosol retrieval over land, J. Geophys. Res., 112, D13210, doi:10.1029/2006JD007815, 2007a.

Levy, R. C., Remer, L. A., Mattoo, S., Vermote, E. F., and Kaufman, Y. J.: Second-generation operational algorithm: retrieval of aerosol properties over land from inversion of moderate resolution imaging spectroradiometer spectral reflectance, J. Geophys. Res., 112, D13211, doi:10.1029/2006JD007811, 2007b.

Li, B., Zhang, J., Zhao, Y., Yuan, S., Zhao, Q., Shen, G., and Wu, H.: Seasonal variation of urban carbonaceous aerosols in a typical city Nanjing in Yangtze River Delta, China, Atmos. Environ., 106, 223-231, 2015.

Li, L., An, J. Y., Zhou, M., Yan, R. S., Huang, C., Lu, Q., Lin, L., Wang, Y. J., Tao, S. K., Qiao, L. P., Zhu, S. H., and Chen, C. H.: Source apportionment of fine particles and its chemical components over the Yangtze River Delta, China during a heavy haze pollution episode, Atmos. Environ. 123, 415-429, 2015.

Mei, L., Xue, Y., de Leeuw, G., Guang, J., Wang, Y., Li, Y., Xu, H., Yang, L., Hou, T., He, X., Wu, C., Dong, J., and Chen, Z.: Integration of remote sensing data and surface observations to estimate the impact of the Russian wildfires over Europe and Asia during August 2010, Biogeosciences, 8, 3771-3791, doi:10.5194/bg-8-3771-2011, 2011.

Oanh, N. T. K., Ly, B. T., Tipayarom, D., Manandhar, B. R., Prapat, P., Simpson, C. D., and Liu, L. J. S.: Characterization of particulate matter emission from open burning of rice straw, Atmos. Environ., 45, 493-502, 2011.

Pio, C. A., Legrand, M., Alves, C. A., Oliveira, T., Afonso, J., Caseiro, A., Puxbaum, H., Sanchez-Ochoa, A., and Gelencsér, A.:
Chemical composition of atmospheric aerosols during the 2003 summer intense forest fire period, Atmos. Environ., 42, 7530 7543, 2008.

Polidori, A., Turpin, B. J., Lim, H.-J., Cabada, J. C., Subramanian, R., Pandis, S. N., and Robinson, A. L.: Local and Regional Secondary Organic Aerosol: Insights from a Year of SemiContinuous Carbon Measurements at Pittsburgh, Aerosol Sci. Technol., 40, 861-872, 2006.

Popovicheva, O., Kistler, M., Kireeva, E., Persiantseva, N., Timofeev, M., Kopeikin, V., and Kasper-Giebl, A.: Physicochemical characterization of smoke aerosol during large-scale wildfires: Extreme event of August 2010 in Moscow, Atmos. Environ., 96, 405-414, 2014.

Quennehen, B., Schwarzenboeck, A., Matsuki, A., Burkhart, J. F., Stohl, A., Ancellet, G., and Law, K. S.: Anthropogenic and forest fire pollution aerosol transported to the Arctic: observations from the POLARCAT-France spring campaign, Atmos. Chem. Phys., 12, 6437-6454, doi:10.5194/acp-12-6437-2012, 2012.

Rolph, G. D.: Real-time Environmental Applications and Display sYstem (READY) Website, http://www.arl.noaa.gov/ready.php, NOAA Air Resources Laboratory, Silver Spring, MD, 2015.

Schauer, J. J., Kleeman, M. J., Cass, G. R., and Simoneit, B. R. T.: Measurement of emissions from air pollution sources. 3. C1-C29 organic compounds from fireplace combustion of wood, Environ. Sci. Tech., 35, 1716-1728, 2001.

Schmidl, C., Marr, I. L., Caseiro, A., Kotianová, P., Berner, A., Bauer, H., Kasper-Giebl, A., and Puxbaum, H.: Chemical characterisation of fine particle emissions from wood stove combustion of common woods growing in mid-European Alpine regions, Atmos. Environ., 42, 126-141, 2008a.

Schmidl, C., Bauer, H., Dattler, A., Hitzenberger, R., Weissenboeck, G., Marr, I. L., and Puxbaum, H.: Chemical characterisation of particle emissions from burning leaves, Atmos. Environ., 42, 9070-9079, 2008b.

Schreier, S. F., Richter, A., Schepaschenko, D., Shvidenko, A., Hilboll, A., and Burrows, J. P.: Differences in satellite-derived $\mathrm{NO}_{x}$ emission factors between Eurasian and North American boreal forest fires, Atmos. Environ., 121, 55-65, 2015.

Sheesley, R. J., Schauer, J. J., Chowdhury, Z., Cass, G. R., and Simoneit, B. R. T.: Characterization of organic aerosols emitted from the combustion of biomass indigenous to South Asia, J. Geophys. Res., 108, 4285, doi:10.1029/2002JD002981, 2003.

Simoneit, B. R. T., Schauer, J. J., Nolte, C. G., Oros, D. R., Elias, V. O., Fraser, M. P., Rogge, W. F., and Cass, G. R.: Levoglucosan, a tracer for cellulose in biomass burning and atmospheric particles, Atmos. Environ., 33, 173-182, 1999.

Stohl, A.: Computation, accuracy and applications of trajectories: A review and bibliography, Atmos. Environ., 32, 947-966, 1998.

Sullivan, A. P., Holden, A. S., Patterson, L. A., McMeeking, G. R., Kreidenweis, S. M., Malm, W. C., Hao, W. M., Wold, C. E., and Collett Jr., J. L.: A method for smoke marker measurements and its potential application for determining the contribution of biomass burning from wildfires and prescribed fires to ambient $\mathrm{PM}_{2.5}$ organic carbon, J. Geophys. Res., 113, D22302, doi:10.1029/2008JD010216, 2008.

Winker, D. M., Vaughan, M. A., Omar, A. H., Hu, Y., Powell, K. A., Liu, Z., Hunt, W. H., and Young, S. A.: Overview of the CALIPSO Mission and CALIOP Data Processing Algorithms, J. Atmos. Oceanic Technol. 26, 2310-2323, 2009. 
Wu, R., Bo, Y., Li, J., Li, L., Li, Y., and Xie, S.: Method to establish the emission inventory of anthropogenic volatile organic compounds in China and its application in the period 2008-2012, Atmos. Environ., 127, 244-254, 2016.
Youn, D., Park, R. J., Jeong, J. I., Moon, B. K., Yeh, S. W., Kim, Y. H., Woo, J. H., Im, E. G., Jeong, J. H., Lee, S. J., and Song, C. K.: Impacts of aerosols on regional meteorology due to Siberian forest fires in May 2003, Atmos. Environ., 45, 1407-1412, 2011. 